University of Nebraska - Lincoln

DigitalCommons@University of Nebraska - Lincoln

Faculty Papers and Publications in Animal

Science

Animal Science Department

January 2004

\title{
A large-sample QTL study in mice: II. Body composition
}

Joao L. Rocha

University of Nebraska-Lincoln

Eugene J. Eisen

North Carolina State University, Raleigh, North Carolina

L. Dale Van Vleck

University of Nebraska-Lincoln, dvan-vleck1@unl.edu

Daniel Pomp

University of Nebraska-Lincoln, dpomp1@unl.edu

Follow this and additional works at: https://digitalcommons.unl.edu/animalscifacpub

Part of the Animal Sciences Commons

Rocha, Joao L.; Eisen, Eugene J.; Van Vleck, L. Dale; and Pomp, Daniel, "A large-sample QTL study in mice: II. Body composition" (2004). Faculty Papers and Publications in Animal Science. 235.

https://digitalcommons.unl.edu/animalscifacpub/235

This Article is brought to you for free and open access by the Animal Science Department at DigitalCommons@University of Nebraska - Lincoln. It has been accepted for inclusion in Faculty Papers and Publications in Animal Science by an authorized administrator of DigitalCommons@University of Nebraska - Lincoln. 


\title{
A large-sample QTL study in mice: II. Body composition
}

\author{
Joao L. Rocha, ${ }^{1, \star}$ Eugene J. Eisen, ${ }^{2}$ L. Dale Van Vleck, ${ }^{3}$ Daniel Pomp ${ }^{1}$ \\ ${ }^{1}$ Department of Animal Science, University of Nebraska, Lincoln, Nebraska 68583-0908, USA \\ ${ }^{2}$ Department of Animal Science, North Carolina State University, Raleigh, North Carolina 27695-7621, USA \\ ${ }^{3}$ USDA, ARS, USMARC, Lincoln, Nebraska 68583-0908, USA
}

Received: 8 July 2003 / Accepted: 10 September 2003

\begin{abstract}
Using lines of mice having undergone long-term selection for high and low growth, a large-sample $\mid n=$ $\sim 1,000 \mathrm{~F}_{2}$ ) experiment was conducted to gain further understanding of the genetic architecture of complex polygenic traits. Composite interval mapping on data from male $\mathrm{F}_{2}$ mice $(n=552)$ detected $50 \mathrm{QTL}$ on 15 chromosomes impacting weights of various organ and adipose subcomponents of growth, including heart, liver, kidney, spleen, testis, and subcutaneous and epididymal fat depots. Nearly all aggregate growth QTL could be interpreted in terms of the organ and fat subcomponents measured. More than $25 \%$ of QTL detected map to MMU2, accentuating the relevance of this chromosome to growth and fatness in the context of this cross. Regions of MMU7, 15, and 17 also emerged as important obesity "hot-spots." Average degrees of directional dominance are close to additivity, matching expectations for body composition traits. A strong QTL congruency is evident among heart, liver, kidney, and spleen weights. Liver and testis are organs whose genetic architectures are, respectively, most and least aligned with that for aggregate body weight. In this study, growth and body weight are interpreted in terms of organ subcomponents underlying the macro aggregate traits, and anchored on the corresponding genomic locations.
\end{abstract}

An estimated $65 \%$ of U.S. adults are overweight, and $31 \%$ are obese (Flegal et al. 2002). Overweight and obesity substantially increase the risk of hyperten-

\footnotetext{
*Present address: Sygen International, 2929 Seventh Street, Berkeley, California 94710, USA.

Correspondence to: D. Pomp; E-mail: dpomp@unl.edu
}

sion, dyslipidemia, type 2 diabetes, coronary heart disease, stroke, gallbladder disease, osteoarthritis, sleep apnea and respiratory problems, and endometrial, breast, prostate, and colon cancers, combining to form the single largest cause of death in developed countries (NHLBI, 1998). While molecular biology has yielded significant advancements in understanding weight regulation at the metabolic and physiological levels, an alarmingly low number of cases of obesity in humans can be attributed to mutations within genes exerting effects in well-characterized, energy-balance pathways (Chagnon et al. 2003).

Carcass and body composition traits also constitute extremely important considerations of modern livestock production systems where consumer health concerns and marketing perspectives play increasingly prominent roles (Lasater and Kingsbery 1987; Smith 1991). The problem of excess fat in livestock and poultry carcasses is ubiquitous and has serious consequences for the animal industry at four levels: health perceptions of consumers; wasteful production of an undesired biological component; labor costs of trimming waste fat; and lower biological efficiencies of fatter animals (Eisen 1989).

Understanding the complex genetic architecture underlying quantitative trait variation for growth and body weight in mice has recently been advanced by use of crosses of large sample sizes, with an emphasis on localizing and defining the nature of QTL for these traits (e.g., Vaughn et al. 1999; Rocha et al. 2004a). While many QTL studies have focused on body fat as a biomedically and agriculturally relevant trait (e.g., reviewed by Pomp 1997; Brockmann and Bevova 2002), fewer investigations have evaluated components of body weight with a more global approach encompassing body fatness as well as organ weights and estimates of lean mass.

We created and evaluated a large sample from an $\mathrm{F}_{2}$ cross between lines of mice that had undergone long-term selection for rapid growth rate and low 
Table 1. Descriptive statistics for organ and fat traits in this study

\begin{tabular}{lcccc}
\hline Traits & $\mathrm{N}$ & $\mu$ & $\sigma$ & Range \\
\hline HRT mg & 551 & 211.8 & 40.5 & $120-425$ \\
LIV mg & 552 & 2274.6 & 389.2 & $1150-3665$ \\
KID mg & 552 & 267.2 & 46.0 & $98-445$ \\
SPL mg & 551 & 142.6 & 41.2 & $63-410$ \\
TES mg & 552 & 105.6 & 19.0 & $46-212$ \\
SCF $^{\mathrm{b}} \mathrm{mg}$ & 552 & 190.6 & 99.9 & $29-688$ \\
EPF $^{\mathrm{b}} \mathrm{mg}$ & 552 & 404.9 & 184.3 & $101-1183$ \\
FAT $^{\mathrm{b}} \mathrm{mg}$ & 552 & 595.5 & 265.3 & $158-1870$ \\
SCF $_{\text {EPF }}$ \% & 552 & 0.49 & 0.17 & $0.10-1.28$ \\
PWAT $^{\mathrm{c}} \%$ & 541 & 63.5 & 3.4 & $42.0-72.5$ \\
\hline
\end{tabular}

${ }^{a}$ HRT, LIV, KID, SPL, TES, SCF, EPF, PWAT are weights of Heart, Liver, Kidney, Spleen, Testis, Subcutaneous fat pad, Epididymal fat pad, and percentage water in carcass. FAT $=(\mathrm{SCF}+\mathrm{EPF})$. All traits measured in F2 males at 10 weaks of age

${ }^{\mathrm{b}}$ Subcutaneous and epididymal fat pad weights, their sum (FAT), and ratio.

${ }^{c}$ Proximal determination of water content of the organism.

body weight to identify QTL for a variety of complex traits, including body weight and growth (Rocha et al. 2004a). In the present study we report on components of growth including weights of many organs and indicators of body fatness and leanness in males of the $\mathrm{F}_{2}$.

\section{Materials and methods}

Relevant information pertaining to the parental high growth (M16i) and low body weight (L6) selection lines, development of the $\mathrm{F}_{2}$ intercross population, and marker genotyping have been presented in a companion paper (Rocha et al. 2004a). Only methods relevant to the specific organ and body composition trait phenotypes evaluated and their statistical data analysis will be described here.

Phenotypes. Ten-week-old males $(n=552)$ from the $F_{2}$ cross described in Rocha et al. (2004a) were weighed (WT10wk) and euthanized by cervical dislocation. Heart (HRT), liver (LIV), spleen (SPL), right kidney (KID), right testis (TES), right hindlimb subcutaneous fat pad (SCF), and right epididymal fat pad (EPF) were immediately excised and wet weights recorded. All organs were returned to the body cavity except for the spleen, which was used for subsequent DNA extraction. Gastrointestinal contents were flushed with tap water, blotted, and wet body weight (w) was recorded. The carcass was then lyophilized to a constant weight (d), and percentage water (PWAT), a proxy for leanness of the organism, was calculated as $100 \times(w-d) / w$. Two additional traits analyzed were FAT, the sum of SCF and EPF, and $\mathrm{SCF} / \mathrm{EPF}$, their ratio. Least squares means for related traits for the grandparental M16i and L6 lines were, respectively, 57.9 vs. $18.4 \mathrm{~g}$ for WT10wk, 7.92 vs. $6.00 \%$ for LIV, 0.23 vs. $0.39 \%$ for TES, and 0.80 vs. $0.67 \%$ for EPF, with weights of organs expressed as percentages of WT10wk.

Data analyses. Descriptive statistics and phenotypic correlations for organ and adipose traits are presented in Tables 1 and 2. Appropriate statistical models were identified for each trait by fitting generalized linear models (PROC GLM; SAS Institute Inc. 1985, 1996), including fixed effects of replicate/ parity, full-sib family/litter, and respective interactions, if significant. Residuals were analyzed with QTL Cartographer (Version 1.15; Basten et al. 2001) to perform composite interval mapping (CIM; Zeng 1993 , 1994). With the exception of SCF/EPF, logarithmic transformation was employed prior to composite interval mapping to correct patterns of heteroscedasticity. Day of tissue harvest was a significant source of phenotypic variation and was included in the statistical models as a nested term within replicate. Interestingly, animals born in litters from the second parity of $F_{1}$ dams tended to exhibit heavier organs but were leaner, an effect that was particularly noticeable for the subcutaneous fat pad (data not shown).

QTL analyses were also performed with three sets of covariate adjustments: 1) WT10wk; 2) FAT; and 3) both WT10wk and FAT. The purpose of these adjustments was to attempt to identify alternate sets of QTL involved in different pathways responsible for the fluctuating patterns of phenotypic and genetic correlations observed among the various traits. In the body weight-adjusted models, relationships of organ and fat weights with WT10wk were always linear and positive (as also evident from phenotypic correlations). Estimates of regression coefficients for WT10wk were negative for PWAT and SCF/EPF. The former was expected, since heavier animals are fatter and PWAT is a proxy for leanness. The latter result may indicate that increased body weight leads to higher rate of deposition of epididymal versus subcutaneous fat. For the FAT-adjusted models, quadratic terms were used in some cases owing to minor deviations from linearity. The sign of the regression coefficient for FAT changed from positive to negative when WT10wk was also used as a covariate, indicating that at a constant body weight, fatter animals tended to have smaller organ weights.

The threshold adopted in the forward-backward stepwise regression factor-selection procedures for CIM was 0.001 for statistical models not including adjustment for WT10wk, and 0.01 when such adjustments were included. A 10-cM window size was 
Table 2. Phenotypic correlations (top row) and QTL congruencies ${ }^{\mathrm{a}}$ (bottom row) among the organ and fat traits ${ }^{\mathrm{b}}$

\begin{tabular}{|c|c|c|c|c|c|c|c|c|c|c|c|}
\hline Traits & HRT & LIV & KID & SPL & TES & SCF & $\mathrm{EPF}$ & FAT $^{\mathrm{c}}$ & $\mathrm{SCF} / \mathrm{EPF}^{\mathrm{d}}$ & PWAT & WT10wk \\
\hline \multirow[t]{2}{*}{ HRT } & 1.0 & 0.49 & 0.53 & 0.31 & 0.11 & $007^{\mathrm{ns}}$ & 0.22 & 0.18 & -0.21 & $0.05^{\mathrm{ns}}$ & 0.49 \\
\hline & & 0.40 & 0.44 & 0.30 & 0.0 & 0.29 & 0.18 & - & 0.0 & 0.0 & 0.22 \\
\hline \multirow[t]{2}{*}{ LIV } & - & 1.0 & 0.66 & 0.57 & 0.21 & 0.27 & 0.40 & 0.38 & -0.13 & -0.14 & 0.81 \\
\hline & & & 0.58 & 0.36 & 0.0 & 0.25 & 0.27 & - & 0.0 & 0.10 & 0.40 \\
\hline \multirow[t]{2}{*}{ KID } & - & - & 1.0 & 0.34 & 0.22 & 0.13 & 0.27 & 0.24 & -0.19 & $-0.00^{\mathrm{ns}}$ & 0.63 \\
\hline & & & & 0.39 & 0.0 & 0.17 & 0.29 & - & 0.0 & 0.11 & 0.35 \\
\hline \multirow[t]{2}{*}{ SPL } & - & - & - & 1.0 & $0.07^{\mathrm{ns}}$ & 0.14 & 0.24 & 0.22 & -0.12 & $0.02^{\mathrm{ns}}$ & 0.53 \\
\hline & & & & & 0.0 & 0.17 & 0.29 & - & 0.0 & 0.11 & 0.35 \\
\hline TES & - & - & - & - & 1.0 & 0.11 & 0.13 & 0.13 & $-0.02^{\mathrm{ns}}$ & $-0.04^{\mathrm{ns}}$ & 0.25 \\
\hline \multirow[t]{2}{*}{ SCF } & - & - & - & - & - & $\begin{array}{l}0.0 \\
1.0\end{array}$ & $\begin{array}{l}0.0 \\
0.72\end{array}$ & $0 . \overline{88}$ & $\begin{array}{l}0.0 \\
0.45\end{array}$ & $\begin{array}{c}0.0 \\
-0.67\end{array}$ & $\begin{array}{l}0.05 \\
0.47\end{array}$ \\
\hline & & & & & & & 0.40 & - & 0.0 & 0.0 & 0.21 \\
\hline \multirow[t]{2}{*}{ EPF } & - & - & - & - & - & - & 1.0 & 0.97 & -0.22 & -0.78 & 0.64 \\
\hline & & & & & & & & - & 0.0 & 0.0 & 0.23 \\
\hline FAT & - & - & - & - & - & - & - & 1.0 & $\begin{array}{l}0.02^{\mathrm{ns}} \\
0.0\end{array}$ & $\begin{array}{c}-0.79 \\
-\end{array}$ & $\begin{array}{c}0.63 \\
-\end{array}$ \\
\hline SCF/EPF & - & - & - & - & - & - & - & - & 1.0 & $\begin{array}{l}0.00^{\text {ns }} \\
0.0\end{array}$ & $\begin{array}{c}-0.16 \\
0.0\end{array}$ \\
\hline PWAT & - & - & - & - & - & - & - & - & - & 1.0 & $\begin{array}{r}-0.36 \\
0.06\end{array}$ \\
\hline
\end{tabular}

aTL common to both traits (overlapping confidence intervals) as a proportion of the total number of QTL detected for the two traits. Cf. legends of Tables 1,3 , and 5 .

${ }^{b}$ HRT, LIV, KID, SPL, TES, SCF, EPF, PWAT are symbols attributed to weights of Heart, Liver, Kidney, Spleen, Testis, Subcutaneous fat pad, Epididymal fat pad, and percentage water in carcass. FAT $=(\mathrm{SCF}+\mathrm{EPF})$. All traits measured in F2 males 10 weeks of age. Correlations for the most part were highly significant $(p<0.0001) ;{ }^{\text {ns }}$ indicates $p>0.05$.

${ }^{\mathrm{c}}$ Relative to QTL for SCF and EPF, no unique results for FAT were found, and it was not considered in the QTL congruency results.

${ }^{\mathrm{d} N o}$ QTL for SCF/EPF were identified.

used. Permutations were performed for organ and fat traits, and when similar results were observed for all traits, their permutations were pooled, leading to adoption of LOD $=3.3$ for the 5\% genomewise significance threshold (Churchill and Doerge 1994; see Rocha et al. 2003a).

\section{Results}

A summary of all identified QTL and related QTL detected by other studies in the same genomic regions are presented in Table 3 . To avoid duplication, results from models including adjustment for WT10wk (designated as HRT\%, KID\%, etc.; Table 3) are presented only when they identified QTL not detected from the unadjusted models. Models including adjustment for FAT identified QTL results similar to those found when not including such adjustments, so they will not be considered further. Results for the composite trait FAT (sum of SCF and EPF) simply reproduced QTL that were detected for the sub-components (subcutaneous and epididymal fat pads), so they will not be reported. Furthermore, no QTL were detected for SCF/EPF, or for WT10wk once this trait was adjusted for all organ weights.

A total of 50 significant QTL were detected, and each was assigned a locus symbol following MGD guidelines (Table 3). QTL (n) were detected for HRT (3), TES (3), LIV (10), KID (7), SPL (9), SCF (4), EPF (5), and PWAT (1). Additional QTL (n) were detected when traits were adjusted for WT10wk, including HRT\% (1), KID\% (2), SCF\% (1), and EPF\% (4). For unadjusted traits, the vast majority of QTL exhibited additive gene action with the M16i allele1 increasing organ and fat pad weights. For traits adjusted for WT10wk, M16i alleles had both positive and negative additive effects depending upon the locus (see Table 3).

Tables 4 and 5 summarize QTL information across traits, while Table 2 presents the QTL-congruencies [QTL common to two traits (overlapping confidence intervals) as a proportion of the total number of QTL detected for the two traits] in relation to the respective phenotypic correlations. Large QTL-congruencies among heart, liver, kidney, and spleen weights are particularly evident, in agreement with phenotypic correlations. Liver weight appears to be controlled by a genetic architecture that is most aligned with body weight, while the reverse is true for testis weight, where no QTL congruencies were found with any other trait.

QTL for most organ and all fat pad weights display a prevalence for additive gene action. Testis and spleen weights, as might be expected given their 
Table 3. QTL detected and respective statistics by chromosome

\begin{tabular}{|c|c|c|c|c|c|c|c|c|}
\hline MMU & Symbol $^{\mathrm{a}}$ & $\begin{array}{l}\text { Flanking } \\
\text { markers }\end{array}$ & $\begin{array}{l}\text { Position }^{\mathrm{c}} \\
\mathrm{cM}\end{array}$ & $a^{\mathrm{d}}$ & $d^{\mathrm{e}}$ & $\% \mathrm{~V}^{\mathrm{f}}$ & LOD & Other studies ${ }^{\mathrm{g}}$ \\
\hline 1 & Lvrq3 & $180-72$ & $\begin{array}{l}59.5 \\
48.9-72.7\end{array}$ & 0.28 & 0.48 & 5.1 & 7.3 & B3 \\
\hline 1 & Splq3 & $72-200$ & $\begin{array}{l}67.4 \\
55.2-78.1\end{array}$ & 0.24 & 0.10 & 3.9 & 5.6 & $\mathrm{~L}, \mathrm{Rb}$ \\
\hline 1 & Pwatq1 & $72-200$ & 72.7 & 0.20 & 0.0 & 3.1 & 3.7 & $\begin{array}{l}\text { B3, L, Mc, Md, } \\
\text { PH, S, T4 }\end{array}$ \\
\hline 1 & Kidq2 & $72-200$ & $\begin{array}{l}51.6-86.6 \\
75.4 \\
70.0-84.7\end{array}$ & 0.31 & -0.12 & 5.9 & 10.2 & B3, I, L \\
\hline 1 & Splq5 & $200-223$ & $\begin{array}{l}93.2 \\
80.9-103.5\end{array}$ & 0.28 & -0.36 & 6.3 & 5.4 & \\
\hline 2 & Hrtq1 & $6-133$ & $\begin{array}{l}52.2 \\
38.0-70.3\end{array}$ & 0.34 & -0.18 & 12.8 & 6.4 & B2 \\
\hline 2 & Kidq1 & $6-133$ & $\begin{array}{l}52.2 \\
42.7-66.8\end{array}$ & 0.43 & 0.57 & 17.2 & 10.3 & B2 \\
\hline 2 & Splq1 & $6-133$ & $\begin{array}{l}57.9 \\
45.6-72.7\end{array}$ & 0.34 & -0.08 & 11.2 & 6.8 & B2, L \\
\hline 2 & Lvrq1 & $6-133$ & $\begin{array}{l}59.7 \\
51.2-69.2\end{array}$ & 0.54 & 0.18 & 23.3 & 18.9 & B2-3, L \\
\hline 2 & Epf\%q2 & 133-224 & $\begin{array}{l}66.8 \\
52.2-72.7\end{array}$ & -0.3 & 0.48 & 1.0 & 3.8 & $\begin{array}{r}\text { B2-3, H, Lb, } \\
\text { M, P, T2-4 }\end{array}$ \\
\hline 2 & Kidq3 & $224-22$ & $\begin{array}{l}77.8 \\
74.0-81.6\end{array}$ & 0.29 & 0.20 & 4.9 & 6.8 & B2 \\
\hline 2 & Lvrq2 & $224-22$ & $\begin{array}{l}79.1 \\
76.5-81.7\end{array}$ & 0.46 & -0.01 & 9.9 & 15.1 & B3 \\
\hline 2 & Splq2 & $224-22$ & $\begin{array}{l}79.1 \\
74.0-83.0\end{array}$ & 0.28 & -0.28 & 4.4 & 5.9 & \\
\hline 2 & Hrtq2 & $224-22$ & $\begin{array}{l}80.4 \\
75.9-84.0\end{array}$ & 0.27 & 0.36 & 5.0 & 5.7 & \\
\hline 2 & $S c f q 1$ & $22-49$ & $\begin{array}{l}84.0 \\
81.7-88.9\end{array}$ & 0.26 & -0.35 & 5.9 & 7.6 & B3, Lb, M, Sc \\
\hline 2 & $\operatorname{Epfq1}$ & $22-49$ & $\begin{array}{l}84.0 \\
79.8-87.6\end{array}$ & 0.31 & -0.47 & 6.7 & 9.5 & B3, Lb, M, Sc \\
\hline 3 & Spla6 & $49-148$ & $\begin{array}{l}95.5-102.4 \\
22.1\end{array}$ & 0.28 & -0.47 & 7.0 & 48 & DO, IVI-Z, I, OC \\
\hline 3 & Lvrq5 & $130-97$ & $\begin{array}{l}10.0-33.2 \\
24.1 \\
14.0-44.7\end{array}$ & 0.28 & 0.31 & 9.7 & 5.3 & B3, L, Md \\
\hline 3 & $H r t \% \mathrm{q} 1$ & 130-97 & $\begin{array}{l}30.2 \\
16.0-53.0\end{array}$ & -0.23 & -0.9 & 4.3 & 3.5 & $\mathrm{~L}, \mathrm{Md}$ \\
\hline 3 & Kidq7 & $97-18$ & $\begin{array}{l}53.0 \\
22.1-65.4\end{array}$ & 0.23 & 0.28 & 8.0 & 3.5 & $\mathrm{~B} 2, \mathrm{~L}, \mathrm{Md}$ \\
\hline 4 & Lvrq9 & $1-27$ & $\begin{array}{l}32.6 \\
15.3-42.5\end{array}$ & 0.25 & 0.11 & 10.3 & 3.9 & $\mathrm{~B} 2-3, \mathrm{Md}$ \\
\hline 4 & Kidq4 & $1-27$ & $\begin{array}{l}42.5 \\
19.5-52.1\end{array}$ & 0.21 & -0.06 & 6.4 & 5.3 & B3, Md \\
\hline 4 & Lvrq 8 & $27-64$ & $\begin{array}{l}49.3 \\
42.5-58.2\end{array}$ & 0.24 & 0.10 & 5.0 & 4.0 & B2-3 \\
\hline 6 & Tesq2 & $132-201$ & $\begin{array}{l}44.9 \\
27.9-56.3\end{array}$ & 0.13 & 2.1 & 7.3 & 4.4 & $\mathrm{Sp}$ \\
\hline 7 & Kidq5 & $55-91$ & $\begin{array}{l}15.0 \\
?-23.1\end{array}$ & 0.21 & 0.38 & 1.9 & 5.3 & B3 \\
\hline 7 & Splq7 & $55-91$ & $\begin{array}{l}16.6 \\
?-24.8\end{array}$ & 0.22 & 0.13 & 3.2 & 4.5 & B3 \\
\hline 7 & Lvrq6 & $55-91$ & $\begin{array}{l}21.5 \\
?-28.1\end{array}$ & 0.23 & -0.31 & 3.0 & 5.0 & B3, T3 \\
\hline 7 & Epfq5 & $55-91$ & $\begin{array}{l}21.5 \\
?-35.9\end{array}$ & 0.19 & -0.41 & 2.6 & 3.4 & $\begin{array}{l}\text { B3, Mc, Md, } \\
\text { PH, T-3, W2 }\end{array}$ \\
\hline 7 & Kidq6 & 11-105 & $\begin{array}{l}63.5 \\
54.5-?\end{array}$ & -0.18 & 0.23 & 1.3 & 3.8 & \\
\hline
\end{tabular}

(Continued) 
Table 3. Continued

\begin{tabular}{|c|c|c|c|c|c|c|c|c|}
\hline MMU & Symbol $^{\mathrm{a}}$ & $\begin{array}{l}\text { Flanking } \\
\text { markers }\end{array}$ & $\begin{array}{l}\text { Position }{ }^{\mathrm{c}} \\
\mathrm{cM}\end{array}$ & $a^{\mathrm{d}}$ & $d^{\mathrm{e}}$ & $\% \mathrm{~V}^{\mathrm{f}}$ & LOD & Other studies ${ }^{g}$ \\
\hline 9 & Splq4 & $105-19$ & $\begin{array}{l}49.7 \\
35.0-58.4\end{array}$ & 0.42 & -0.81 & 16.0 & 5.6 & B3, L \\
\hline 10 & Kid\%q2 & $1-65$ & $\begin{array}{l}11.8 \\
?-23.4\end{array}$ & 0.09 & -3.7 & 7.0 & 3.4 & \\
\hline 10 & Hrtq3 & $1-65$ & $\begin{array}{l}27.3 \\
13.7-44.6\end{array}$ & 0.26 & -0.12 & 6.2 & 4.2 & $\mathrm{~L}$ \\
\hline 10 & $S c f \% q 1$ & $1-65$ & $\begin{array}{l}33.1 \\
20.5-55.3\end{array}$ & -0.19 & -2.3 & 12.0 & 3.9 & B3 \\
\hline 10 & Lvrq4 & $1-65$ & $\begin{array}{l}37.0 \\
26.3-53.2\end{array}$ & 0.23 & -1.3 & 7.4 & 5.5 & B3 \\
\hline 10 & Tesq3 & $65-35$ & $\begin{array}{l}69.0 \\
58.2-?\end{array}$ & -0.19 & -0.36 & 3.3 & 3.9 & LeR \\
\hline 11 & Epfq4 & $2-4$ & $\begin{array}{l}17.4 \\
?-34.9\end{array}$ & 0.22 & 0.43 & 2.5 & 3.5 & B-2-3, Mc, Md \\
\hline 11 & Kid\%q1 & $2-4$ & $\begin{array}{l}19.9 \\
6.2-39.1\end{array}$ & -0.25 & -1.2 & 6.1 & 4.5 & B-2-3, I, L, Md \\
\hline 11 & Lvrq7 & $2-4$ & $\begin{array}{l}24.9 \\
11.1-45.4\end{array}$ & 0.24 & 0.05 & 2.7 & 4.6 & B-2-3, L, Md \\
\hline 11 & $S c f q 3$ & $2-4$ & $\begin{array}{l}24.9 \\
9.9-47.5\end{array}$ & 0.23 & 0.05 & 3.8 & 4.1 & B-2-3, F, Mc, Md \\
\hline 12 & Lvrq10 & $5-8$ & $\begin{array}{l}53.2 \\
43.5-?\end{array}$ & 0.21 & -0.06 & 2.4 & 3.5 & $\mathrm{~B} 2-3, \mathrm{Md}$ \\
\hline 13 & Tesq1 & $3-21$ & $\begin{array}{l}10.0 \\
?-14.6\end{array}$ & 0.26 & 0.12 & 4.0 & 7.2 & B3, LeR, Z \\
\hline 14 & Epf\%q1 & $50-34$ & $\begin{array}{l}20.3 \\
?-34.5\end{array}$ & -0.30 & -0.33 & 5.3 & 6.0 & B3 \\
\hline 15 & Scf $q 2$ & $13-1$ & $\begin{array}{l}25.2 \\
8.8-39.6\end{array}$ & -0.26 & 0.35 & 5.0 & 4.4 & B2-3, G, H, P, PH, W, Wd, Y \\
\hline 15 & Epf\%q4 & $13-1$ & $\begin{array}{l}33.4 \\
21.1-46.3\end{array}$ & -0.25 & 0.66 & 3.4 & 3.4 & $\mathrm{~B} 3, \mathrm{G}, \mathrm{H}, \mathrm{K}, \mathrm{P}, \mathrm{PH}, \mathrm{W}$ \\
\hline 15 & Epf\%q3 & $1-15$ & $\begin{array}{l}51.1 \\
46.3-?\end{array}$ & -0.26 & 0.07 & 3.3 & 3.6 & $\mathrm{~B} 3, \mathrm{~K}, \mathrm{PH}$ \\
\hline 16 & Splq8 & $55-57$ & $\begin{array}{l}3.4 \\
?-10.2\end{array}$ & 0.03 & -7.5 & 2.0 & 3.9 & \\
\hline 17 & Splq9 & $124-10$ & $\begin{array}{l}21.9 \\
?-32.4\end{array}$ & 0.19 & 0.08 & 2.4 & 3.4 & B2 \\
\hline 17 & $\operatorname{Scf} q 4$ & $124-10$ & $\begin{array}{l}21.9 \\
?-34.0\end{array}$ & 0.20 & -0.08 & 3.4 & 4.1 & B3, M2, Md, P, PH, T2-4 \\
\hline 17 & $E p f q 3$ & $124-10$ & $\begin{array}{l}21.9 \\
?-33.2\end{array}$ & 0.21 & 0.03 & 3.0 & 3.8 & B3, M2, Md, P, PH, T2-4 \\
\hline
\end{tabular}

${ }^{a}$ Hrtq, Lvrq, Kidq, Splq, Tesq, Scfq, Egfq, Pwatq are symbols attributed to QTL detected for weights of Heart, Liver, Kidney, Spleen, Testis, Subcutaneous fat pad, Epididymal fat pad, and percentage water in carcass. Symbols with \% represent traits adjusted for 10-week body weight. Numeric indices of QTL reflect a descending rank of their maximum LOD scores within trait.

${ }^{\mathrm{b}}$ MIT markers (e.g., within MMU 1, 180 represents D1Mit180).

${ }^{\mathrm{c}}$ Approximate positions (Mouse Genome Database) of maximum likelihood peaks (top) and respective one LOD confidence intervals (bottom). A '?' indicates that a confidence interval extends to the beginning or end of a chromosome.

${ }^{\mathrm{d}}$ Additive effect (Falconer and Mackay 1996) in phenotypic S.D. units (transformed scale). Negative values indicate increasing effect of the L6 allele.

${ }^{\text {e}}$ Degree of relative dominance: 0 indicates additivity; 1, full dominance of the M16i allele; and -1, full dominance of the $L 6$ allele.

${ }^{\mathrm{f}}$ Percentage of phenotypic variance accounted for by QTL.

${ }^{\text {g}}$ Studies detecting QTL for similar traits in the same genomic region, listed in order of location on each chromosome (from proximal to distal). B, B2, and B3 are, respectively, Brockmann et al. (1998a, 1998b, 2000); F, Fisler and Warden (1997); G, Gu et al. (1999); H, Horvat et al. (2000); I, Iakoubova et al. (1995); K, Keightley et al. (1998); L, Leamy et al. (2002); Lb, Lembertas et al. (1997); LeR, Le Roy et al. (2001); M and M2, Mehrabian et al. (1998, 2000); Mc, Machleder et al. (1997); Md, Moody et al. (1999); P, Pomp (1997); PH, Purcell-Huynh et al. (1995); Rb, Roberts et al. (2000); S, Suto et al. (1999); Sc, Schadt et al. (2003); Sp, Spearow et al. (1999); T and T2, Taylor and Phillips (1996, 1997); T3 and T4, Taylor et al. (1999, 2001); W and W2, West et al. (1994, 1995); Wd, Warden et al. (1995); Y, York et al. (1996); and Z, Zidek et al. (1998). 
Table 4. Summary of estimates of QTL effects and gene action across traits

\begin{tabular}{|c|c|c|c|c|c|c|c|c|}
\hline Trait $^{\mathrm{a}}$ & \#QTL ${ }^{b}$ & \#Chr ${ }^{\mathrm{b}}$ & Avg. $a^{\mathrm{c}}$ & Max. $a$ & Min. $a$ & Avg. $d^{\mathrm{d}}$ & $\operatorname{Max} . d$ & Min. $d$ \\
\hline HRT & 3 & 2 & 0.29 & 0.34 & 0.26 & 0.02 & 0.36 & -0.18 \\
\hline LIV & 10 & 8 & 0.30 & 0.54 & 0.21 & -0.05 & 0.48 & -1.3 \\
\hline KID & 7 & 5 & 0.27 & 0.43 & -0.18 & 0.15 & 0.57 & -0.12 \\
\hline SPL & 9 & 7 & 0.25 & 0.42 & 0.03 & -1.0 & 0.13 & -7.5 \\
\hline TES & 3 & 3 & 0.19 & 0.26 & -0.19 & 0.86 & 2.1 & -0.36 \\
\hline SCF & 4 & 4 & 0.24 & 0.26 & -0.26 & -0.18 & 0.35 & -0.35 \\
\hline EPF & 5 & 4 & 0.24 & 0.31 & 0.19 & -0.08 & 0.43 & -0.47 \\
\hline PWAT & 1 & 1 & 0.20 & - & - & 0.0 & - & - \\
\hline HRT\% & 1 & 1 & 0.23 & - & - & -0.9 & - & - \\
\hline KID\% & 2 & 2 & 0.17 & 0.09 & -0.25 & -1.3 & -1.2 & -3.7 \\
\hline SCF\% & 1 & 1 & 0.19 & - & - & -2.3 & - & - \\
\hline EPF\% & 4 & 3 & 0.28 & -0.25 & -0.30 & 0.22 & 0.66 & -0.33 \\
\hline
\end{tabular}

a HRT, LIV, KID, SPL, TES, SCF, EPF, PWAT are weights of Heart, Liver, Kidney, Spleen, Testis, Subcutaneous fat pad, Epididymal fat pad, and percentage water in carcass. Symbols with \% represent traits adjusted for 10-week body weight. QTL for adjusted traits detected in same genomic regions as QTL detected from unadjusted models were not included.

${ }^{b}$ Number of QTL and number of chromosomes in which QTL were detected for the trait.

${ }^{\mathrm{c}}$ Average of absolute values of $a$.

${ }^{\mathrm{d}}$ Average of degree of directional dominance (not average of absolute values of $d$ ).

Table 5. Summary of magnitudes of QTL effects across traits

\begin{tabular}{|c|c|c|c|c|c|c|c|}
\hline Trait $^{\mathrm{a}}$ & Avg $\%$ Var & Max \% Var & Min $\%$ Var & Total \% Var $^{\mathrm{b}}$ & First $5 \% \operatorname{Var}^{\mathrm{c}}$ & Last $5 \% \operatorname{Var}^{\mathrm{d}}$ & $\operatorname{Avg~} \mathrm{CI}^{\mathrm{e}}$ \\
\hline HRT & 8.0 & 12.8 & 5.0 & $\begin{array}{l}19.0 \\
(26.0)\end{array}$ & - & - & $\begin{array}{l}23.8 \\
(32.3-8.1)\end{array}$ \\
\hline LIV & 7.9 & 23.3 & 2.4 & $(\overline{86.3)}$ & 34.5 & 17.4 & $\begin{array}{l}22.7 \\
(34.3-5.2)\end{array}$ \\
\hline KID & 6.5 & 17.2 & 1.3 & $\overline{(44.3)}$ & 24.1 & 12.4 & $\begin{array}{l}24.5 \\
(43.3-7.6)\end{array}$ \\
\hline SPL & 6.3 & 16.0 & 2.0 & $\begin{array}{c}- \\
(65.7)\end{array}$ & 26.5 & 13.9 & $\begin{array}{l}21.4 \\
(27.1-9.0)\end{array}$ \\
\hline TES & 4.9 & 7.3 & 3.3 & $\begin{array}{l}10.7 \\
(13.7)\end{array}$ & - & - & $\begin{array}{l}28.4 \\
(-)\end{array}$ \\
\hline SCF & 4.5 & 5.9 & 3.4 & $\begin{array}{l}19.5 \\
(31.6)\end{array}$ & - & - & $\begin{array}{l}25.2 \\
(37.6-7.2)\end{array}$ \\
\hline $\mathrm{EPF}$ & 3.8 & 6.7 & 2.5 & $\begin{array}{l}15.8 \\
(43.7)\end{array}$ & - & - & $\begin{array}{l}7.4 \\
(7.8-6.9)\end{array}$ \\
\hline PWAT & 3.1 & - & - & $\begin{array}{l}3.1 \\
(4.4)\end{array}$ & - & - & $\begin{array}{l}35.0 \\
(-)\end{array}$ \\
\hline HRT\% & 4.3 & - & - & $\begin{array}{l}4.3 \\
(-)\end{array}$ & - & - & $\begin{array}{l}37.0 \\
(-)\end{array}$ \\
\hline $\mathrm{KID} \%$ & 6.6 & 7.0 & 6.1 & $\begin{array}{l}12.5 \\
(-)\end{array}$ & - & - & $\begin{array}{l}32.9 \\
(-)\end{array}$ \\
\hline $\mathrm{SCF} \%^{\mathrm{e}}$ & 12.0 & - & - & $\begin{array}{l}12.0 \\
(-)\end{array}$ & - & - & $\begin{array}{l}34.8 \\
(-)\end{array}$ \\
\hline $\mathrm{EPF} \%$ & 3.3 & 5.3 & 1.0 & $\begin{array}{l}11.1 \\
(-)\end{array}$ & - & - & $\begin{array}{l}22.9 \\
(25.2-20.5)\end{array}$ \\
\hline
\end{tabular}

${ }^{a}$ HRT, LIV, KID, SPL, TES, SCF, EPF, PWAT are weights of Heart, Liver, Kidney, Spleen, Testis, Subcutaneous fat pad, Epididymal fat pad, and percentage water in carcass. Symbols with \% represent traits adjusted for 10-week body weight. QTL for adjusted traits detected in same genomic regions as QTL detected from unadjusted models were not included.

${ }^{\mathrm{b}}$ Total percentage of phenotypic variance accounted for by all QTL detected for a trait. For some traits, the large number of QTL detected precluded estimation of this statistic. In parentheses is the percentage of the F2 range accounted for when additive effects (2a) of all QTL detected for a trait are summed (transformed scale).

${ }^{\mathrm{c}}$ Total percentage of the phenotypic variance accounted for by largest five QTL.

${ }^{\mathrm{d}}$ Total percentage of the phenotypic variance accounted for by smallest five (or remaining) QTL.

${ }^{\mathrm{e}}$ Average length (range) of the one LOD confidence intervals defined for the trait QTLs (situations where one of the CI boundaries could not be defined are excluded from this average). In parentheses are the corresponding maximum and minimum lengths of such CIs. 


\section{Chromosome 2 - Composite Interval Mapping}

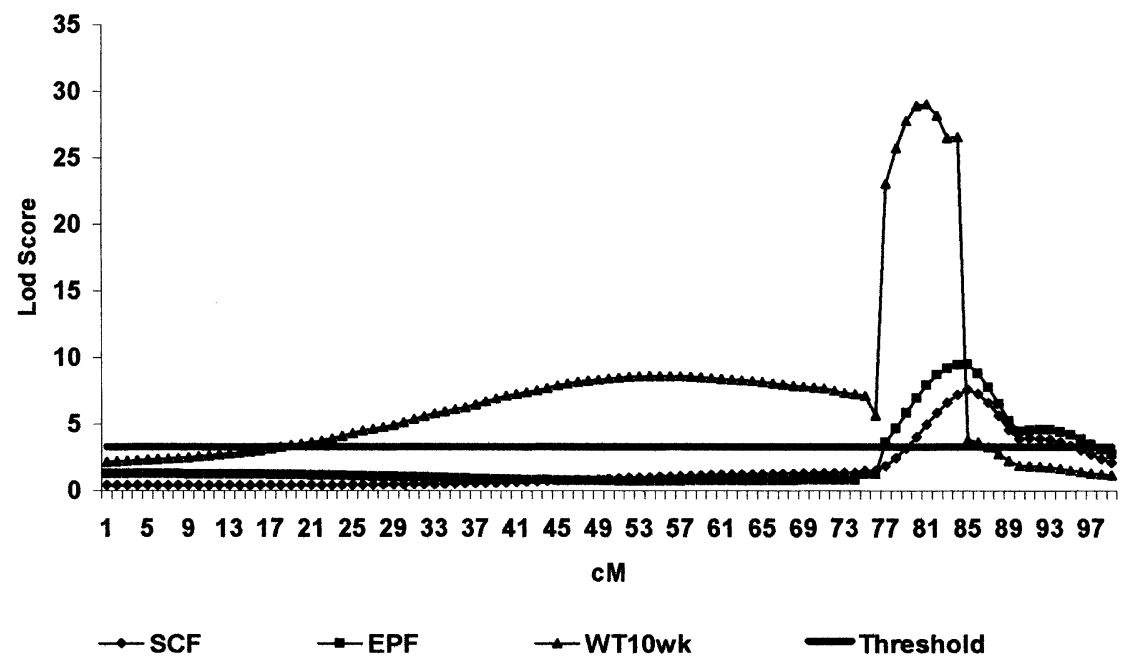

Fig. 1. QTL likelihood plots for Chr 2 resulting from Composite Interval Mapping for 10-week body weight (WT10wk) and weights of subcutaneous (SCF) and epidydimal (EPF) fat depots. respective roles in reproduction and disease resistance, both exhibited relatively strong directional dominance. The limited explorations of epistasis that were conducted (see Rocha et al. 2004a for methods) revealed little evidence for interactions among QTL affecting individual organ and fat pad weights.

Nearly $25 \%$ (12) of detected QTL are located on Chromosome (Chr) 2, reflecting the large effects detected for aggregate body weight (Rocha et al. 2004a) and reproduction (Rocha et al. 2004c) traits. Likelihood plots for Chr 2 QTL for fat traits are provided in Fig. 1. QTL peaks for fat traits appear to match the peak representing the more distal QTL for WT10wk (Rocha et al. 2004a). This potentially pleiotropic locus likely reflects patterns of fat deposition with increasing maturity and the strong correlation between weight and fat in mice.

Fitting of alternative statistical models, with or without covariate adjustments, provides in some cases indirect evidence for existence of multiple linked QTL for the same trait. One such example for the case of potentially two QTL for SPL detected on MMU1 is illustrated in Fig. 2. This plot could represent a statistical artifact from the fitting of simple QTL models. However, the fact that adjustment for body weight differentially impacts the two putative and linked QTL lends some support to the possibility that these are in fact two distinct yet linked QTL, one impacting SPL independent of body weight. Formal tests comparing two QTL models relative to single QTL models will be employed in the future across this entire data set.

Figures 3 and 4 schematically summarize the genomic bases of components of 10-week body weight. Only rarely were QTL detected for organ and fat traits that did not overlap with the confidence intervals of QTL that had previously been detected for aggregate growth traits (Rocha et al. 2004a). The unique relevance of $\mathrm{Chr} 2$ in the context of this cross is further demonstrated.

\section{Discussion}

Obesity exacts an immense economic and social toll, accounting for $\sim 7 \%$ of US health expenditures and leading to potential bias and discrimination in employment, education, and health care (NHLBI 1998). It is an exceptionally complex disorder, with relatively equal contributions of multifactorial genetic susceptibility and interacting environmental factors (Pomp 1997). Predisposition to obesity results from combinations of relatively small effects of genetic variations within a large number of polygenes (QTL; Brockmann and Bevova 2002) of yet unidentified function.

The present results, in combination with a concurrent analysis of growth and body weight (Rocha et al. 2004a), have added new information to the predisposition map for mouse body weight regulation, and have further partitioned body weight QTL in terms of adipose tissue and weights of various organs. The vast majority of growth QTL, impacting different age periods, can be interpreted in terms of fat and organ subcomponents measured. Muscle, bone, gut, skin, and various small organs were not measured in this experiment. Many studies (Belknap et al. 1992; Brockmann et al. 2000; Williams 2000; Airey et al. 2001; Williams et al. 2001; Leamy et al. 2002) have identified QTL for several of these unmeasured subcomponents which match some of the growth QTL identified in the present study that have 
Chromosome 1 - Evidence supporting two linked QTL

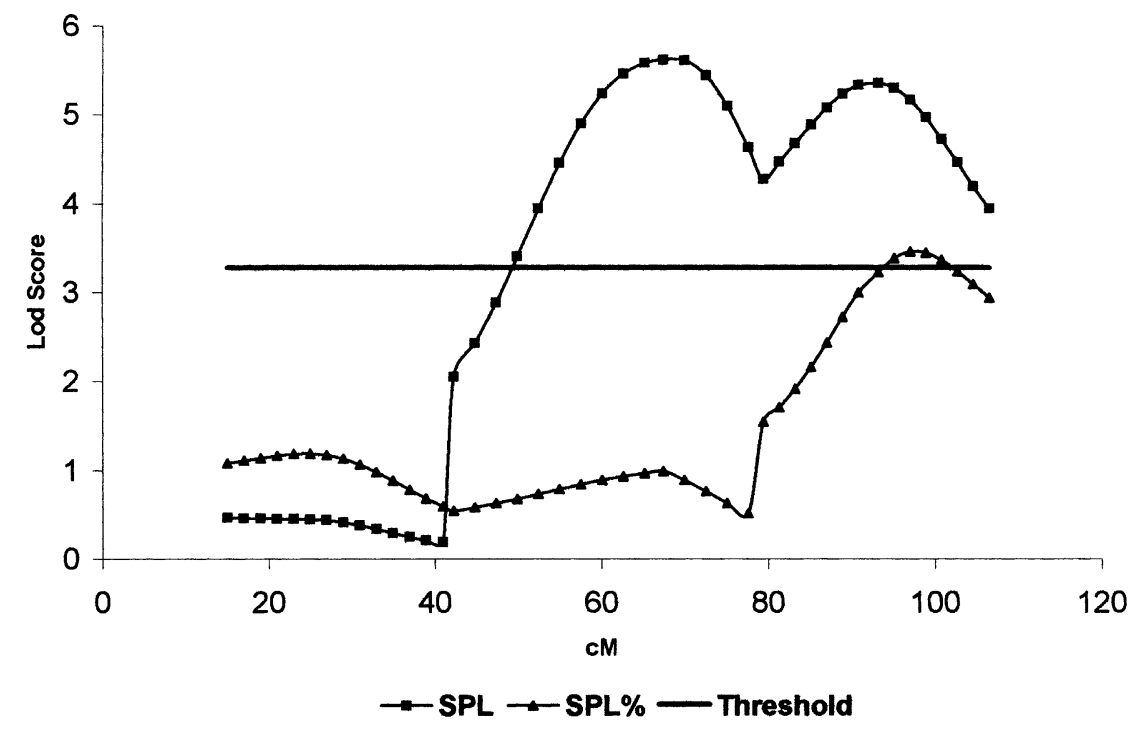

Fig. 2. QTL likelihood plots for Chr 1 resulting from Composite Interval Mapping for spleen weight by fitting alternative statistical models: with (SPL\%) and without (SPL) covariate adjustment for body weight. unknown underlying subcomponents. Additionally, only a few QTL (and primarily those with small effects) detected for organ subcomponents in this study did not overlap with confidence intervals of QTL that were detected for the aggregate growth traits (Rocha et al. 2004a).

Our results strongly re-emphasize the observation of Mehrabian et al. (1998) regarding commonality of genomic regions impacting obesity traits across many different genetic backgrounds. The QTL for fatness we report on Chr 2, 7, 15, and 17 appear to be obesity genomic hot-spots, although caution is required when assuming that the underlying genes in each region are identical in each genetic background.

Large effects of QTL impacting aggregate growth of the organism, growth of most organs, and especially fatness are present on mouse Chr 2 . In regard to obesity predisposition, distal $\mathrm{Chr} 2$ appears to be one of the most relevant regions of the mouse genome. Not only is this region well populated with multiple body weight and fatness QTL as determined from crosses employing different approaches and genetic backgrounds (Lembertas et al. 1997; Pomp 1997; Mehrabian et al. 1998; Schadt et al. 2003a), the QTL harbored in this region in the M16 selection line appear to have among the largest effects of any body weight regulating polygenes ever localized. Since distal MMU2 and HSA20 (from p13 through q13) form continuous stretches of synteny between the two species, identification of the genes underlying obesity QTL in this region of the mouse represents an excellent opportunity for comparative mapping and application of murine models to stud- ies of human health. The importance of this is amplified by the findings from several groups that the homologous region of HSA20 harbors genes influencing predisposition to obesity and diabetes in humans (see Chagnon et al. 2003).

Efforts to identify and characterize the M16based distal MMU2 weight and fat QTL are under way (Jerez-Timaure et al. 2002; Pomp et al. 2002). Our detailed studies in this region using M16i and an M16i.B6-(D2Mit306-D2Mit52) congenic line (referred to as MB2) strongly indicate the presence of multiple linked QTL with effects on weight and fatness (Jerez-Timaure and Pomp, unpublished). Efforts at positional cloning are further complicated by the fact that this region of the mouse genome is known to contain many genes involved in regulation of energy balance. For these reasons, success in this endeavor will likely require experimental approaches that combine functional analyses with the resolving power of recombination.

A new paradigm for bridging the gap between our knowledge of the physiology and predisposition of obesity is to combine QTL mapping with large-scale gene expression analysis. Transcriptome mapping, also called "genetical genomics" (Jansen and Nap 2001; Jansen 2003), treats levels of gene expression of any particular gene measured across different individuals as an expression-level polymorphism that in principle reflects the underlying genetic variation (Dumas et al. 2000; Jansen and Nap 2001; Doerge 2002). This type of analysis was pioneered by de Vienne et al. (1994), using proteomic evaluation [later extended by the same group to the transcriptome (Consoli et al. 2002)] in an $F_{2}$ population of 
MMU1 (2 QTL)

MMU2 (2 QTL)
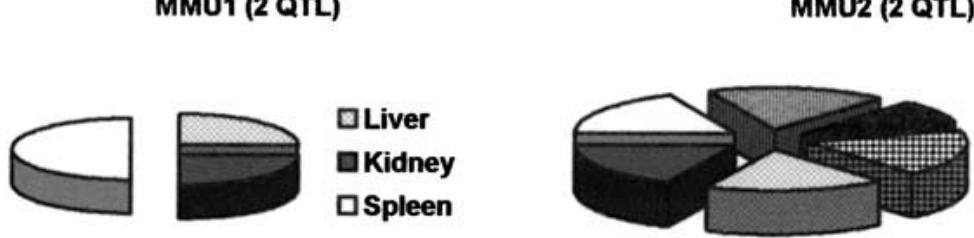

口Liver

aKidney

口Spleen

口Heart

- Scutfat

田Epidfat

MMU3 (2 QTL)

MMU4

MMU5

口Liver
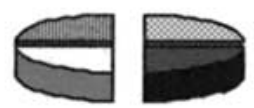

Kidney

$\square$ Spleen

口LIver

口KIdney

口Unknown

$\square$ Heart

MMU6

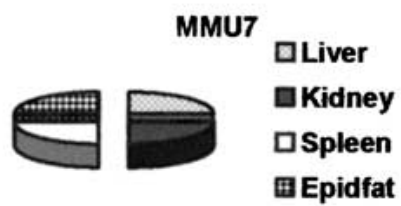

MMU8

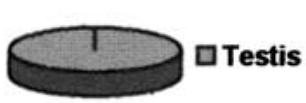

田Epidfat

口Unknown

MMU9

MMU10 (2 QTL)

MMU11

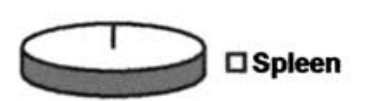

ㅁiver

口Liver
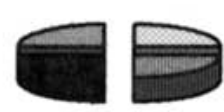

口Heart

- Scutfat

口Testis



MMU13

MMU17 (2 QTL)

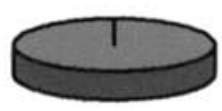

\section{口Unknown}
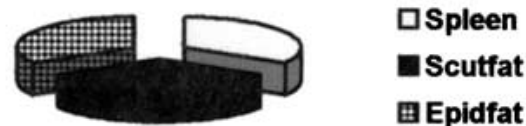

Fig. 3. Chromosomes responsible for 10-week body weight, as assessed from the results of Rocha et al. (2004a), and corresponding assignments in terms of organ and fat subcomponents based on overlapping confidence intervals. In some cases, unequal relative areas represent different numbers of QTL detected for the different traits. On MMU1, two QTL for spleen were found, while other organs are represented by a single QTL. On MMU2 all organs are represented by two QTL except for SCF (subcutaneous fat), for which only one QTL was localized. 


\section{A. Relative numbers of QTL for the different organ and fat traits across the different growth periods}

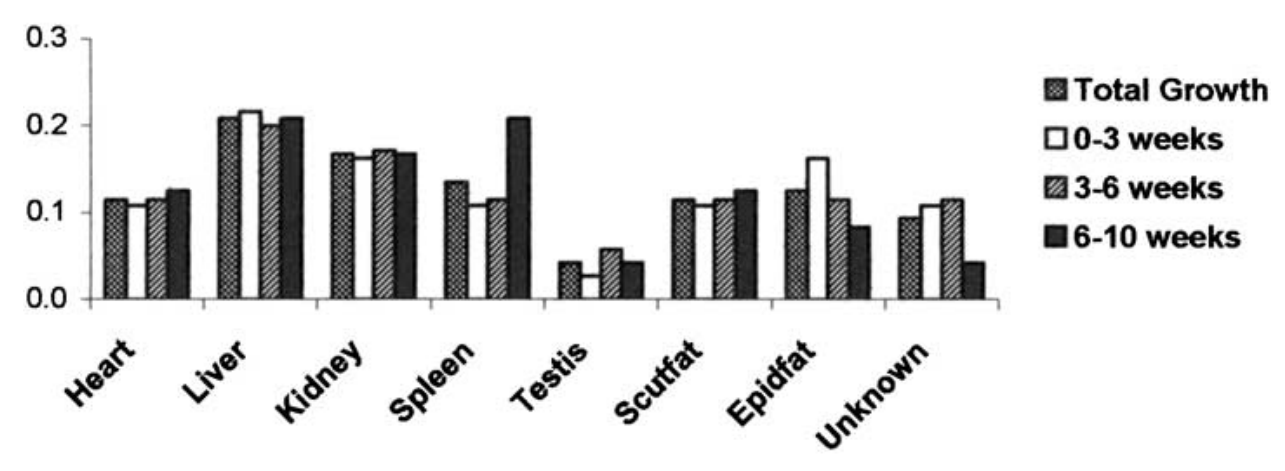

\section{B: Relative numbers of QTL (all organs) contributed by the different chromosomes to the total growth process}

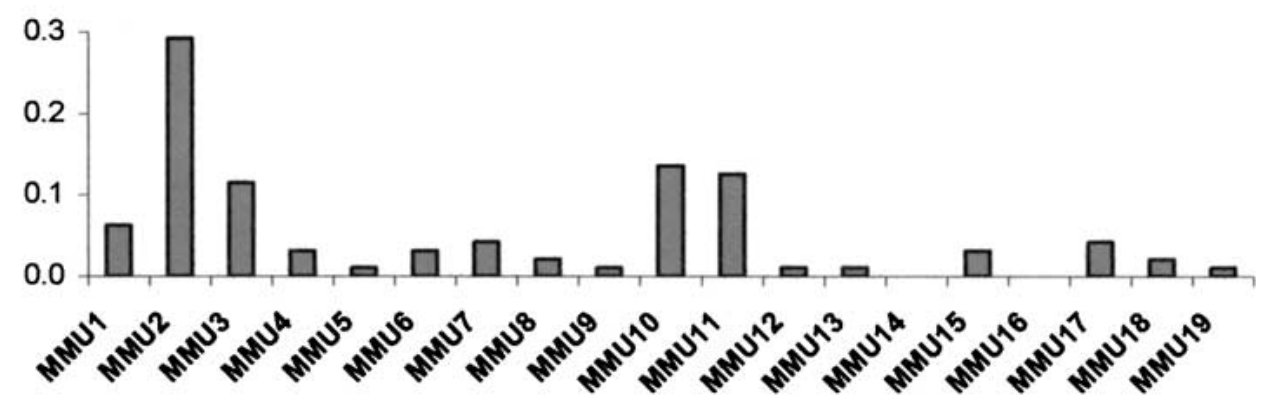

Fig. 4. A) relative numbers of QTL associated with each of the subcomponent organ and fat traits (under the broad general assumption that body composition evaluated at 10 weeks harbors relevant information regarding body composition changes in each growth period); and B), relative contributions of each chromosome to the total growth process in terms of QTL numbers for all organs.

maize. Transcriptome mapping is a powerful mechanism to dissect complex traits and make more efficient the selection of candidate genes underlying predisposition loci, with recent successful implementation in yeast (Brem et al. 2002), Drosophila (Wayne and McIntyre 2002), and mice (Schadt et al. 2003a, 2003b).

By identifying expression QTL that coincided with a QTL peak for, and had correlations with, subcutaneous fat mass, Schadt et al. (2003a) proposed the NM_025575 and NM_15731 genes as primary candidates for the distal MMU2 QTL for dietary-induced obesity described by Lembertas et al. (1977). These candidate genes also possibly overlap with the obesity QTL we identified in this region.
Important distinctions exist between the results from Schadt et al. (2003a) and those from the present experiment. Distinctly different genetic models were used. Obesity in the M16 line does not require high levels of dietary fat. Indeed, no interactions between dietary fat consumption and effects of MMU2 QTL on body fat levels were found when comparing the M16i selection line and MB2. This lack of interaction is noteworthy given that the donor line for MB2 is C57, which is one of the strains used in the Schadt et al. (2003a) study, and which is among the strains most responsive to dietaryinduced obesity (West et al. 1992). Nevertheless, localization of candidate genes identified by Schadt et al. (2003a) at $\sim 165 \mathrm{MB}$ on distal MMU2 aligns 
with the QTL peak for the Epfq2 locus, representing the more distal of the two obesity QTL found in our study and the one with significantly smaller effects. However, preliminary data from our subsequent fine-mapping efforts with MB2 indicate that the best supported position for Epfq2 may be at $159 \mathrm{MB}$ (Jerez-Timaure and Pomp, unpublished).

QTL for specific organ weights that support findings from independent studies are those for testis weight on the proximal region of MMU13, spleen weight on MMU1 (more proximal of the two detected), and kidney weight on MMU11. In this respect, MMU11 is second in importance to MMU2 in regard to effects on components of body weight in the context of this cross. Surprisingly, the only QTL detected for percentage water in the carcass did not match any of the QTL detected for fat traits, which may reflect the different nature of the two phenotypes. PWAT exhibits much less variability than SCF or EPF and is impacted not only by fat content but also by protein and mineral content. Nevertheless, results from other studies provide some support for the existence of a QTL for PWAT on MMU1, through both an impact on fat content (Purcell-Huynh et al. 1995; Machleder et al. 1997; Moody et al. 1999; Suto et al. 1999; Taylor et al. 2001) and/or mineral content (Leamy et al. 2002).

Liver and testis are those organs whose weights have the largest and the smallest numbers of QTL, respectively. Liver weight is the most aligned with growth of the overall organism, while testis weight is the least aligned with overall growth. Strong QTL congruencies exist among liver, heart, kidney, and spleen weights, in agreement with phenotypic correlations and paralleling results reported by other studies that have undertaken detailed organ subcomponent analyses (Kramer et al. 1998; Brockmann et al. 2000; Leamy et al. 2002). The latter two studies, which included comprehensive QTL analyses for organ and fat subcomponents, corroborate many of our present findings. Such agreement is not surprising, especially in regard to Leamy et al. (2002) and Pomp (1997), who analyzed data from a cross that also utilized the M16i selection line.

An interesting finding from this study concerns how different covariate adjustments may in some cases provide strong evidence supporting the existence of multiple linked QTL. Average additive QTL effects and average variance QTL effects for body composition traits are relatively larger than those reported for the aggregate growth traits (Rocha et al. 2004a). This may represent differences in genetic architecture of the traits, but more likely reflects the smaller sample size in the body composition analysis, which will tend to lead to estimates having an upward bias (Beavis 1998; Melchinger et al. 1998; Utz et al. 2000).

Directional dominance is not expected to play much of a role for the organ and fat traits studied at 10 weeks of age, as heterosis observed for corresponding traits in livestock species is usually minimal. Estimates of dominance effects match that expectation, with small average values reflecting predominantly additive gene action. Testis and spleen weights provide exceptions. This would perhaps be expected for testis weight, given the classical relevance of dominance and heterosis for reproductive (fitness) traits. Regarding spleen weight, the high average dominance values may be related to the involvement of this organ in disease-resistance mechanisms, which are traits for which dominance and heterosis are generally important.

Comparisons of the total amount of variance accounted for by all QTL, when fitted together, and the sum of the individual fractions of variance explained by individual QTL provide limited evidence about the relevance of epistatic interactions on phenotypic expression of these traits (i.e., with no epistasis, the two values should coincide). On the basis of this approach, organ and fat subcomponents of body weight appear to be traits for which epistasis is especially not important. However, validation of this finding requires more thorough statistical approaches (i.e., fitting of multiple QTL models).

While molecular biology has yielded advancements in understanding weight regulation at the metabolic and physiological levels [see reviews by Bray and Tartaglia (2000) and Barsh and Schwartz (2002)], the genetic architecture of obesity remains essentially undefined. And while QTL maps for obesity-related traits are well represented in both mice (Brockmann and Bevova 2002) and humans (Chagnon et al 2003), only a few isolated cases of obesity in humans can be attributed to mutations within genes exerting effects in well-characterized, energy-balance pathways (Chagnon et al. 2003). This gap between our knowledge of physiological mechanisms underlying obesity and the nature of genetic predisposition to obesity greatly impairs the ability to identify relevant QTL, which in turn limits development of gene-based tools for diagnosing, treating, and eventually preventing obesity and related diseases. Our future objective is to use the M16 obesity model to integrate genetics and physiology and resolve the macro level of phenotypic expression in terms of successive subcomponent layers (e.g., de Vienne et al. 1994; Flint and Mott 2001; Schadt et al. 2003a, 2003b) to the level of integrated and interacting pathways of biochemical networks. When this approach is anchored with a sound understand- 
ing of the corresponding genomic organization responsible for the operation of physiological systems, resolution at the level of single genes or integrated sets of interacting genes may become more readily attainable.

\section{Acknowledgments}

We gratefully acknowledge Mary Ann Cushman, Stephenie Foster, and Grady Beck for collection of genotypic data. J.L. Rocha acknowledges the support of the Portuguese Foundation for Science and Technology. This research is a contribution of the University of Nebraska Agricultural Research Division (Lincoln, neb.; Journal Series No. 14110) and the North Carolina Agricultural Research Service, and was supported in part by funds provided through the Hatch Act. This research was also partially based upon work supported by the National Science Foundation under Grant No. 0091900 (Nebraska EPSCOR infrastructure improvement grant).

\section{References}

1. Airey DC, Lu L, Williams RW (2001) Genetic control of the mouse cerebellum: identification of quantitative trait loci modulating size and architecture. J Neurosc 21, 5099-5109

2. Barsh GS, Schwartz MW (2002) Genetic approaches to studying energy balance: perception and integration. Nat Rev Genet 3, 589-600

3. Basten CJ, Weir BS, Zeng Z-B (2001) QTL Cartograher, version 1.15 (Raleigh, NC: North Carolina State University)

4. Beavis WD (1998) Power, precision, and accuracy. In Molecular Dissection of Complex Traits, AH Paterson, ed. (Boca Raton, Fla: CRC Press), pp 145-162

5. Belknap JK, Phillips TJ, O'Toole LA (1992) Quantitative trait loci associated with brain weight in the BXD/ Ty recombinant inbred mouse strains. Brain Res Bull $29,337-344$

6. Bray GA, Tartaglia LA (2000) Medicinal strategies in the treatment of obesity. Nature 404, 672-677

7. Brem RB, Yvert G, Clinton R, Kruglyak L (2002) Genetic dissection of transcriptional regulation in budding yeast. Science $296,752-755$

8. Brockmann GA, Bevova MR (2002) Using mouse models to dissect the genetics of obesity. Trends Genet $18,367-376$

9. Brockmann GA, Renne U, Kopplow K, Das P (1998a) Genetic markers for the detection of quantitative trait loci with special consideration of body weight and fat. Acta Theriol (Suppl 5), 43, 53-62

10. Brockmann GA, Haley CS, Renne U, Knott SA, Schwerin M (1998b) Quantitative trait loci affecting body weight and fatness from a mouse line selected for extreme high growth. Genetics 150, 369-381

11. Brockmann GA, Kratzsch J, Haley CS, Renne U, Schwerin M, et al. (2000) Single QTL effects, epistasis, and pleiotropy account for two-thirds of the phenotypic $\mathrm{F}_{2}$ variance of growth and obesity in DU6i $\times$ DBA/2 mice. Genome Res 10, 1941-1957

12. Chagnon YC, Rankinen T, Snyder EE, Weisnagel SJ, Perusse L, et al. (2003) The human obesity gene map: the 2002 update. Obes Res 11, 313-367

13. Churchill GA, Doerge RW (1994) Empirical threshold values for quantitative trait mapping. Genetics 138, 963-971

14. Consoli L, Lefevre A, Zivy M, de Vienne D, Damerval C (2002) QTL analysis of proteome and transcriptome variations for dissecting the genetic architecture of complex traits in maize. Plant Mol Biol 48, 575581

15. de Vienne D, Maurice A, Josse JM, Leonardi A, Damerval C (1994) Mapping factors controlling genetic expression. Cell Mol Biol (Noisy-le-Grand) 40, 29-39

16. Doerge RW (2002) Mapping and analysis of quantitative trait loci in experimental populations. Nat Rev Genet 3, 43-52

17. Dumas P, Sun Y, Corbell G, Trenblay S, Pausova Z, et al. (2000) Mapping of quantitative trait loci (QTL) of differential stress gene expression in rat recombinant inbred strains. Hypertens 18, 545-551

18. Eisen EJ (1989) Selection experiments for body composition in mice and rats: a review. Livest Prod Sci 23 $17-32$

19. Falconer DS, Mackay TF (1996) Introduction to Quantitative Genetics (Harlow, UK: Longman Group Ltd.)

20. Fisler JS, Warden CH (1997) Mapping of mouse obesity genes: a generic approach to a complex trait. J Nutr 127(Suppl), 1909S-1916S

21. Flegal KM, Carroll MD, Ogden CL, Johnson CL (2002) Prevalence and trends in obesity among US adults, 1999-2000. JAMA (J am Med Assoc) 288, 17231727

22. Flint J, Mott R (2001) Finding the molecular basis of quantitative traits: successes and pitfalls. Nat Rev Genet 2, 437-445

23. Gu L, Johnson MW, Lusis AJ (1999) Quantitative trait locus analysis of plasma lipoprotein levels in an autoimmune mouse model. Arterioscler Thromb Vase Biol $19,442-453$

24. Horvat S, Bunger L, Falconer VM, Mackay P, Law A, et al. (2000) Mapping of obesity QTLs in a cross between mouse lines divergently selected on fat content. Mamm Genome 11, 2-7

25. Lakoubova OA, Dushkin H, Beier DR (1995) Localization of a murine recessive polycystic kidney disease mutation and modifying loci that affect disease severity. Genomics 26, 107-114

26. Jansen RC (2003) Studying complex biological systems using multifactorial perturbation. Nat Rev Genet 4, $145-151$ 
27. Jansen RC, Nap JP (2001) Genetical genomics: the added value from segregation. Trends Genet 17, 388391

28. Jerez-Timaure N, Pomp D, Eisen EJ (2002) Confirmation of quantitative trait loci (QTL) affecting body weight and fatness in a congenic line of mice. J Anim Sci 80 (Suppl 2), 45 (abst)

29. Keightley PD, Morris KH, Ishikawa A, Falconer VM, Oliver F (1998) Test of candidate gene-quantitative trait locus association applied to fatness in mice. Heredity $81,630-637$

30. Kramer MG, Vaughn TT, Pletscher LS, Ellison KK, Adams E, et al. (1998) Genetic variation in body weight gain and composition in the intercross of Large (LG/J) and Small (SM/J) inbred strains of mice. Genet Mol Biol 21, 211-218

31. Lasater L, Kingsbery B (1987) The New Cattle Industry, 1st ed. (Woodinville, Washington: Kingsbery Communications)

32. Leamy LJ, Pomp D, Eisen EJ, Cheverud JM (2002) Pleiotropy of quantitative trait loci for organ weights and limb bone lengths in mice. Physiol Genomics 10, 21-29

33. Lembertas AV, Perusse L, Chagnon YC, Fisler JS, Warden $\mathrm{CH}$, et al. (1997) Identification of an obesity quantitative trait locus on mouse chromosome 2 and evidence of linkage to body fat and insulin on the human homologous region 20q. J Clin Invest 100, 12401247

34. Le Roy I, Tordjman S, Samour DM, Degrelle H, Roubertoux PL (2001) Genetic architecture of testis and seminal vesicle weights in mice. Genetics 158, 333-340

35. Machleder D, Ivandic B, Welch C, Castellani L, Reue K, et al. (1997) Complex genetic control of HDL levels in mice in response to an atherogenic diet. J Clin Invest 99, 1406-1419

36. Mehrabian M, Wen P-Z, Fisler J, Davis RC, Lusis AJ (1998) Genetic loci controlling body fat, lipoprotein metabolism, and insulin levels in a multifactorial mouse model. J Clin Invest 101, 2485-2496

37. Mehrabian M, Castellani LW, Wen P-Z, Wong J, Rithaporn T, et al. (2000) Genetic control of HDL levels and composition in an interspecific mouse cross (CAST/Ei × C57BL/6J). J Lipid Res 41, 1936-1946

38. Melchinger AE, Utz HF, Schon CC (1998) Quantitative trait locus (QTL) mapping using different testers and independent population samples in maize reveals low power of QTL detection and large bias in estimates of QTL effects. Genetics 149, 383-403

39. Moody DE, Pomp D, Nielsen MK, Van Vleck LD (1999) Identification of quantitative trait loci influencing traits related to energy balance in selection and inbred lines of mice. Genetics 152, 699-711

40. NHLBI (1998) Clinical Guidelines on the Identification, Evaluation, and Treatment of Overweight and Obesity in Adults: The Evidence Report. NIH Publication No. 98-4083

41. Pomp D (1997) Genetic dissection of obesity in polygenic animal models. Behav Genet 27, 285-306
42. Pomp D, Jerez-Timaure N, Allan MF, Eisen EJ (2002) Integrated genomic, proteomic and metabolomic dissection of polygenic selection response for murine growth and fatness. Proc $7^{\text {th }}$ World Congr Genet Appl Livest Prod 32, 447-450

43. Purcell-Huynh DA, Weinreb A, Castellani LW, Mehrabian M, Doolittle MH, et al. (1995) Analysis of a genetic cross between inbred mouse strains NZB/BINJ and SM/J using a complete linkage map approach. J Clin Invest 96, 1845-1858

44. Roberts AW, Hasegawa M, Metcalf D, Foote SJ (2000) Identification of a genetic locus modulating splenomegaly induced by granulocyte colony-stimulating factor in mice. Leukemia 14, 657-661

45. Rocha JL, Eisen EJ, Van Vleck LD, Pomp D (2004a) A large-sample QTL study in mice: I. Growth. Mamm Genome 15, 83-99

46. Rocha JL, Siewerdt F, Eisen EJ, Van Vleck LD, Pomp D (2004c) A large-sample QTL study in mice: III. Reproduction. Mamm Genome, in press

47. SAS Institute Inc. (1985) SAS User's Guide: Basics (Cary, N.C.: SAS)

48. SAS Institute Inc. (1996) SAS System for Mixed Models (Cary, N.C.: SAS)

49. Schadt EE, Monks SA, Drake TA, Lusis AJ, Che N, et al. (2003a) Genetics of gene expression surveyed in maize, mouse and man. Nature 422, 297-302

50. Schadt EE, Monks SA, Friend SH (2003b) A new paradigm for drug discovery: integrating clinical, genetic, genomic and molecular phenotype data to identify drug targets. Biochem Soc Trans 31, 437-443

51. Smith GC (1991) Responding to a changing consumer: repositioning beef in the diet-safety, nutrient content and palatability. In The King Ranch and the Texas A\&M University System: Partners in Progress since 1891 (College Station, TX: Texas A\&M University), pp M1-M11

52. Spearow JL, Nutson PA, Mailliard WS, Porter M, Barkley M (1999) Mapping genes that control hormoneinduced ovulation rate in mice. Biol Reprod 61, 857872

53. Suto J, Matsuura S, Yamanaka H, Sekikawa K (1999) Quantitative trait loci that regulate plasma lipid concentration in hereditary obese $\mathrm{KK}$ and $\mathrm{KK}-\mathrm{A}^{\mathrm{y}}$ mice. Biochim Biophys Acta 1453, 385-395

54. Taylor BA, Phillips SJ (1996) Detection of obesity QTLs on mouse chromosomes 1 and 7 by selective DNA pooling. Genomics 34, 389-398

55. Taylor BA, Phillips SJ (1997) Obesity QTLs on mouse chromosomes 2 and 17. Genomics 43, 249-257

56. Taylor BA, Tarantino LM, Phillips SJ (1999) Genderinfluenced obesity QTLs identified in a cross involving the KK type II diabetes-prone mouse strain. Mamm Genome 10, 963-968

57. Taylor BA, Wnek C, Schroeder D, Phillips SJ (2001) Multiple obesity QTLs identified in an intercross between the NZO (New Zealand obese) and the SM (small) mouse strains. Mamm Genome 12, 95103 
58. Utz HF, Melchinger AE, Schon CC (2000) Bias and sampling error of the estimated proportion of genotypic variance explained by quantitative trait loci determined from experimental data in maize using cross validation and validation with independent samples. Genetics 154, 1839-1849

59. Vaughn TT, Pletscher LS, Peripato A, Ellison KK, Adams E, et al. (1999) Mapping quantitative trait loci for murine growth: a closer look at genetic architecture. Genet Res Camb 74, 313-322

60. Warden CH, Fisler JS, Shoemaker SM, Wen P-Z, Svenson KL, et al. (1995) Identification of four chromosomal loci determining obesity in a multifactorial mouse model. J Clin Invest 95, 1545-1552

61. Wayne ML, McIntyre LM (2002) Combining mapping and arraying: an approach to candidate gene identification. Proc Natl Acad Sci USA 99, 14903-14906

62. West DB, Boozer CN, Moody DL, Atkinson RL (1992) Dietary obesity in nine inbred mouse strains. Am J Physiol 262, R1025-R1032

63. West DB, Lefevre JG, York B, Truett GE (1994) Dietary obesity linked to genetic loci on chromosomes 9 and 15 in a polygenic mouse model. J Clin Invest 94, 14101416

64. West DB, Truett GE, Lefevre JG, York B (1995) Loci on chromosomes $4,7,9,12$, \& 15 control a significant proportion of the dietary obesity phenotype in the mouse. FASEB J 9, A722

65. Williams RW (2000) Mapping genes that modulate mouse brain development: a quantitative genetic approach. In Mouse Brain Development, Results and Problems in Cell Differentiation, vol 30, Goffinet AM and Rakic P, eds. (Berlin, Germany: Springer-Verlag), pp 21-49

66. Williams RW, Airey DC, Kulkarni A, Zhou G, Lu L (2001) Genetic dissection of the olfactory bulbs of mice: QTLs on four chromosomes modulate bulb size. Behav Genet 31, 61-77

67. York B, Lei K, West DB (1996) Sensitivity to dietary obesity linked to a locus on chromosome 15 in a CAST/Ei $\times$ C57BL/6J F $F_{2}$ intercross. Mamm Genome 7, 677-681

68. Zeng Z-B (1993) Theoretical basis for separation of multiple linked gene effects in mapping quantitative trait loci. Proc Natl Acad Sci USA 90, 1097210976

69. Zeng Z-B (1994) Precision mapping of quantitative trait loci. Genetics 136, 1457-1468

70. Zidek V, Musilova A, Pintir J, Simakova M, Pravenec M (1998) Genetic dissection of testicular weight in the mouse with the BXD recombinant inbred strains. Mamm Genome 9, 503-505 